\title{
Łukasz Kraj
}

UNIWERSYTET JAGIELLOŃSKI W KRAKOWIE

\section{Dwa Źródła Aretuzy. Semantyka, literackie właściwości i funkcjonowanie aspektów kompozycji Karola Szymanowskiego w sonecie Jarosława Iwaszkiewicza}

Celem poniższych rozważań jest z jednej strony próba przedstawienia, w jaki sposób i w jakim zakresie konstrukcja i semantyka dzieła muzycznego mogą funkcjonować na terytorium dzieła literackiego, z drugiej zaś przybliżenie związków pomiędzy tekstami kultury z dwóch odrębnych obszarów sztuki przy wykorzystaniu zarówno narzędzi poetyki opisowej, jak i podstawowego instrumentarium różnorodnie rozumianej analizy dzieła muzycznego ${ }^{1}$. To komparatystyczne przedsięwzięcie starałem się przeprowadzić w oparciu o syntezę dotychczasowych refleksji teoretycznych i propozycji w zakresie metodologii badań dotyczących tego zagadnienia, często ograniczonych jedynie do wybranych jego aspektów. W niniejszym artykule chcę także poruszyć problem rozumienia treści niesionych przez muzykę i próby ich poetyckiego zapisu przez Jarosława Iwaszkiewicza

1 Por. I.D. Bent, Analiza. Polski przekład hasła $z$ „The New Grove Dictionary of Music and Musicians", tłum. J. Rybicki, [w:] Analiza i interpretacja dzieła muzycznego. Wybór metod, red. T. Malecka, Kraków 1990, seria „Introductio Musicae”, t. 4, s. 9. 
- poetę-kompozytora. Badanie muzycznej semantyki i modyfikacji, jakim ulega ona po przesunięciu na obszar literatury, wymaga jednak uzupełnienia krótkim, choć niekiedy skomplikowanym wywodem literaturoznawczym.

Jak pisze badacz związków muzyki i literatury Andrzej Hejmej, nie ma konwencjonalnych sposobów przenoszenia zjawisk muzycznych (na przykład w zakresie konstrukcji) do literatury, stąd analiza takich relacji ma zawsze charakter jednorazowy, opiera się na konkretnych przykładach ${ }^{2}$. W tym wypadku przedmiotem badań są dwa teksty: muzyczny poemat Źródło Aretuzy Karola Szymanowskiego i sonet o tym samym tytule Jarosława Iwaszkiewicza ${ }^{3}$. Taki dobór artystów tłumaczy się nie tylko niepodważalną relacją intertekstualną ich dzieł, ale i wieloletnią przyjaźnią, wspólną pracą ${ }^{4}$ oraz dobrą wzajemną znajomością twórczości. Proces porównawczy nie jest jednak łatwy wobec długiej i bogatej tradycji badań nad związkami muzyki i literatury, tym bardziej że niektórzy badacze kwestionują sensowność i możliwość jego przeprowadzenia. Warto jednak podjąć się tego zadania, choćby ze względu na wspomniany wyżej indywidualny charakter muzyczno-literackich relacji, wymagający równie zindywidualizowanego postępowania badawczego.

Poruszając się po niebezpiecznym terenie pogranicza sztuk, należy zacząć od pytania o możliwość przeprowadzenia miarodajnej analizy i wyciągnięcia przekonywających wniosków. „Fałszem jest, jakoby utwór literacki był w stanie wywołać jakiekolwiek doznania muzyczne"s. To kategoryczne i bezkompromisowe stwierdzenie zawarł Tadeusz Szulc w swojej pracy Muzyka w dziele literackim, w której nie tylko wyklucza on możliwość „muzycznego” recypowania literatury, ale w ogóle neguje sensowność praktycznie wszystkich badań związków pomiędzy tymi obszarami sztuki. Do tak nieprzejednanego stanowiska popychają badacza dwa fakty: odrębność statusów ontologicznych

2 A. Hejmej, Muzyczność dzieła literackiego, Wrocław 2002, s. 64, 66.

3 Wiersz cytuję za wydaniem: J. Iwaszkiewicz, Wiersze zebrane, Warszawa 1968, s. 401.

4 Przykładem może być stworzenie przez Iwaszkiewicza libretta do opery Król Roger Szymanowskiego. Takich wspólnych działań było oczywiście więcej.

5 T. Szulc, Muzyka w dziele literackim, Warszawa 1936, s. 77; cyt. za: Cz. Zgorzelski, Elementy „muzyczności” w poezji lirycznej, [w:] Muzyka w literaturze. Antologia polskich studiów powojennych, red. A. Hejmej, Kraków 2002, s. 81. 
dzieła literackiego oraz muzycznego i wynikająca z niej niemożność przenoszenia metodologii pomiędzy badaniami nad nimi. Co więcej,

z perspektywy semiologii nie daje się mówić o żadnej adekwatnej odpowiedniości pomiędzy systemem językowym a systemem muzycznym ze względu przede wszystkim [...] na brak znaków transsystemowych ${ }^{6}$.

Muzyce w literaturze Szulc skłonny jest przyznać jedynie miejsce przedmiotu w rzeczywistości dzieła literackiego - przedmiotu równorzędnego wobec innych ${ }^{7}$.

W istocie nie sposób podważyć lub ominąć tak logicznych konkluzji, a jednak stanowisko Szulca nie uśmierciło komparatystyki literacko-muzycznej, ale przeciwnie - dało jej impuls do dalszego rozwoju, oczyszczając badania literackie z nieprecyzyjnych, zaczerpniętych z muzyki określeń o impresywnym charakterze i wysokim stopniu zmetaforyzowania ${ }^{8}$. Już po wojnie zaczęły pojawiać się nowe, ostrożniejsze badania, propozycje klasyfikacji i definiowania związków dwóch obszarów sztuki. W oparciu o te różnorodne, często wzajemnie komentujące się postulaty można sformułować ogólne stwierdzenie, że chociaż transpozycja tworzywa muzycznego na językowe jest rzeczywiście niemożliwa, to byłoby błędem zignorowanie ewidentnych intertekstualnych nawiązań, nierzadko jasno sugerowanych przez autora, a czasem wręcz wprost wskazywanych przez niego w komentarzu lub wstępie $e^{9}$ Argument ten wspierają pojawiające się w nauce stwierdzenia, że nawet pomiędzy dwoma różnymi systemami znaków „istnieje jakaś, mniej lub bardziej ograniczona i utrudniona, możliwość korespondencji” ${ }^{10}$. Różnie rozumiana muzyka może istnieć w dziele literackim na wiele sposobów - jako ukształtowanie eufoniczne i prozodyjne, jako przedmiot wszelkiego rodzaju tematy-

6 A. Hejmej, Muzyczność..., dz. cyt., s. 7.

7 T. Szulc, dz. cyt., s. 87; cyt. za: Cz. Zgorzelski, dz. cyt., s. 81.

8 Cz. Zgorzelski, dz. cyt., s. 81; A. Hejmej, Muzyczność..., dz. cyt., s. 37-39. Hejmej dokonuje pobieżnego przeglądu przedwojennych badań literackich i unaocznia wyraźną tendencję do postrzegania literatury przez pryzmat muzyki także wśród badaczy.

9 Przykładem takiej relacji może być przedmowa Jarosława Iwaszkiewicza do opowiadania Martwa pasieka, w której każe on czytać swoje dzieło w odniesieniu do kompozycji Igora Strawińskiego. Zob. J. Iwaszkiewicz, Martwa pasieka, [w:] Opowiadania muzyczne, Warszawa 1971, s. 288. Jak jednak zauważa Hejmej, tego typu wskazówki nie zawsze okazują się prawdziwe. Zob. tenże, Muzyczność..., dz. cyt., s. 50.

10 A. Barańczak, Poetycka „muzykologia”, [w:] Muzyka w literaturze. Antologia..., dz. cyt., s. $37-44$. 
zacji oraz jako matryca, za pomocą której pisarz konstruuje utwór ${ }^{11}$. Używając tej klasyfikacji, można badać obecność konkretnego utworu muzycznego w literaturze.

\section{Tytuł}

W interesującym mnie przykładzie współistnienia kompozycji i wiersza podstawowym ogniwem sprzęgającym teksty będzie tytuł - Źródło Aretuzy. Już sama jego tożsamość może być sygnałem pewnej intersemiotycznej relacji ${ }^{12}$, jednak o ile tytuł sonetu możemy chwilowo rozpatrywać jedynie jako element uzależniający rozumienie utworu od kompozycji Szymanowskiego, o tyle nazwę samej kompozycji, powstałej wcześniej i przez to niezależnej od hipertekstu ${ }^{13}$, należy postrzegać wieloaspektowo ze względu na jej „właściwości konotacyjne” („,referencjalne”) ${ }^{14}$ czy „naddane” ${ }^{15}$. Jest to o tyle ważne, że sonet Iwaszkiewicza jako hipertekst nosi w sobie pośrednio wszystkie znaczenia przywoływane przez tytuł hipotekstu. Zadaniem tytułu dzieła muzycznego jest

\section{[...] budzenie pewnych konotacji, często o charakterze ogólnym, nie chodzi bowiem, a w każdym razie nie musi chodzić, o procedury ilustracyjne, tytuł ma powiązać dzieło z pewnymi ogólnymi wartościami, sugerować jego głębię, na- prowadzać na znaczenia. Ma też potęgować właściwości konotacyjne zawarte w samym dziele ${ }^{16}$.}

W myśl tej zasady można pokusić się o próbę skonkretyzowania obszarów, które w sposób bardzo ogólny konotuje tytuł. Wśród osób

11 A. Hejmej, Muzyczność..., dz. cyt., s. 52.

12 Por. J. Iwaszkiewicz, Książka o Sycylii, Warszawa 2000, s. 138-140. Sformułowanie „źródło Aretuzy” budzi w pisarzu trojakie skojarzenia - z mitem, z Syrakuzami oraz z dziełem przyjaciela. W swoim dziele o włoskiej wyspie Iwaszkiewicz poetycką prozą określa swoje rozumienie kompozycji Szymanowskiego. Utwierdza to w przekonaniu, że wiersz należy czytać w perspektywie intertekstualnej.

13 „Hipertekst” rozumiem zgodnie z koncepcją Gérarda Genettea jako tekst, którego istnienie uzależnione jest od tekstu wcześniejszego (hipotekstu). W dalszej części pracy postaram się wykazać, że tak w istocie jest.

14 M. Głowiński, Literackość muzyki - muzyczność literatury, [w:] Muzyka w literaturze. Antologia..., dz. cyt., s. 105.

15 A. Barańczak, Jak muzyka znaczy, „Teksty” 1976, nr 6, s. 120.

16 M. Głowiński, dz. cyt., s. 105-106. 
o pewnym zorientowaniu w kulturze „źródło Aretuzy” może zatem budzić skojarzenia zarówno z Owidiuszowską mityczną historią o nimfie uciekającej przed adoratorem ${ }^{17}$ (co bynajmniej nie implikuje ilustracyjnego charakteru muzyki ${ }^{18}$, a jedynie subtelnie wiąże kompozycję z opowieścią), jak i związaną z mitem, ale funkcjonującą w świecie fizycznym fontanną na włoskiej wyspie Ortygii ${ }^{19}$. Przywołuję te konkretyzacje, ponieważ będą miały znaczenie w analizie pokrewieństwa znaczeń kompozycji i sonetu. Oczywiście, konotacji możebyćo wiele więcej, mogą sięone różnićstopniem skonkretyzowania w zależności od wiedzy posiadanej przez odbiorcę, mogą też pozostać na poziomie nieokreślonych ,jakości emocjonalnych” odpowiadających opowieściom przywoływanym przez tytuły konkretnych Mitów ${ }^{20}$. Tytuł kompozycji Szymanowskiego zawsze będzie miał charakter arbitralny, czyli będzie sugerował - prawdziwe bądź nie - przyczynki, impulsy do powstania utworu ${ }^{21}$, i przez to otwierał perspektywy interpretacji intertekstualnej, określał „relacje zewnętrzne” dzieła. Należą do nich wymienione powyżej konotacje w jakimś stopniu określające lub uzupełniające „relacje wewnętrzne”22, lecz nie tylko.

17 Zob. R. Graves, Mity greckie, tłum. H. Krzeczkowski, Warszawa 1968, s. 88. Historię tę przyjmuje Teresa Chylińska jako jedyne źródło inspiracji dla kompozytora. Por. taż, Karol Szymanowski i jego epoka, Kraków 2008, t. 1, s. 334.

18 M. Głowiński, Gatunki literackie w muzyce, [w:] Klasycy współczesnej polskiej myśli humanistycznej, red. A. Nowakowski, t. 2, Narracje literackie i nieliterackie, Kraków 1997, s. 185. Innego zdania jest Tadeusz Zieliński, który wprost mówi o „natarczywej ilustracyjności” i do kolejnych segmentów kompozycji usiłuje przypasować sceny z opowieści. Por. tenże, Szymanowski. Liryka i ekstaza, Kraków 1997, s. 109-111.

19 O takich skojarzeniach nie wspomina bezpośrednio autorka monografii o K. Szymanowskim. O wpływie Sycylii na kompozytora pisze jednak w innym dziele: Szymanowski i jego muzyka, Warszawa 1990, s. 40-41. Podobną opinię wyraża Tadeusz Zieliński (por. tenże, dz. cyt., s. 109.). Myślę, że związek podróży po Sycylii w 1914 roku i kształtu dzieła powstałego rok później warto pozostawić przynajmniej w sferze hipotezy, na co zresztą wskazuje sam Iwaszkiewicz w cytowanej tu już Książce o Sycylii (s. 58-59). O rehabilitacji kontekstu biograficznego w badaniach muzykologicznych por. M. Tomaszewski, Między inspiracją a rezonansem. Dzieło muzyczne w perspektywie intertekstualnej, [w:] Analiza dzieła muzycznego. Historia, theoria, praxis, t. 1, red. D. Kanafa, Wrocław 2010, s. 13.

20 S. Dąbrowski, „Muzyka w literaturze” (próba przeglądu zagadnień), [w:] Muzyka w literaturze. Antologia..., dz. cyt., s. 160.

21 M. Głowiński, Literackość muzyki..., dz. cyt., s. 106-107.

22 M. Tomaszewski, dz. cyt., s. 11. 
Tytuł jest w tym przypadku swego rodzaju „pomostem” pomiędzy konkretnym utworem a tekstem późniejszym, sonetem. Specyfika dzieła muzycznego każe zwrócić uwagę na jego genezę, a także na jego znaczenie w przyszłości, „rezonans”, który być może wywołuje ${ }^{23}$. Nie ulega wątpliwości, że tak jest w tym przypadku, tytuł Źródło Aretuzy stanowi element kompozycji funkcjonujący poza muzyką - w aspekcie czasu przeszłego (inspiracja) i przyszłego (rezonans). Jest też pierwszym elementem przeniesionym przez Jarosława Iwaszkiewicza do sonetu, jednym z ogniw pośredniczących pomiędzy kompozycją a wierszem.

\section{Gatunki - właściwości i różnice}

Tytuł dzieła muzycznego ze względu na swój literacki charakter może bez przeszkód zaistnieć w utworze literackim, jednak przeniesienie gatunku muzycznego na grunt literatury, czego zresztą Iwaszkiewicz nie próbuje robić, nie przychodzi już tak łatwo. Znowu jednak, podobnie jak w przypadku tytułu, zwraca uwagę „,iterackość” gatunku kompozycji. Mity. Trzy poematy na skrzypce i fortepian op. 30 - tak brzmi pełny tytuł muzycznego tryptyku. Słowem-kluczem w zakresie możliwości przeniesienia muzyki w obszar dzieła literackiego będzie zatem nazwa gatunku - poemat. Nazwanie Źródła Aretuzy „poematem” nie implikuje opowiedzenia historii materiałem dźwiękowym, co byłoby niemożliwe z punktu widzenia semiotyki, lecz, podobnie jak w przypadku tytułu, polega raczej na otworzeniu konkretniejszych, choć wciąż niedookreślonych perspektyw recepcji, nieobecnych w przypadku odbioru kompozycji bez „literackiego” tytułu. Recepcja ta może być wzbogacona o czynnik analogii pomiędzy dziełem muzycznym a wypowiedzią literacką ${ }^{24}$. Poemat w kontekście muzyki można więc określić jako gatunek otwierający pewne drogi dla intertekstualności w aspekcie genologicznym, opierający recepcję muzyki na różnie konstruowanych analogiach do literatury (np. szukanie podobieństw do elementów narracji, ogólnego nastroju). W tytule cyklu istnieje również inna nazwa gatunku, i to gatunku, który mimo wielości definicji

23 Tamże, s. 17. Autor mówi o wpływie dzieła na „muzykę następnych pokoleń”, sądzę jednak, że można rozszerzyć znaczenie „rezonansu” dzieła także na inne teksty kultury.

24 M. Głowiński, Gatunki..., dz. cyt., s. 186. 
wciąż często jest odczuwalny jako literacki. Mowa o micie. Nazwa nasuwa skojarzenia formalne - z pewną literacką narracją - oraz w pewnym stopniu semantyczne - mity są wszak jednym z filarów kultury europejskiej.

Jednak Iwaszkiewicz dla swojego Źródła Aretuzy wybiera formę o bardzo słabych, jeśli jakichkolwiek, związkach z muzyką, co więcej - formę zgoła nienarracyjną. Ale sonet pojawia się u Iwaszkiewicza nie bez powodu. Gatunek ten jest historycznie związany z Sycylią ${ }^{25}$, która odbija się echem w kompozycji Szymanowskiego. Sonet to forma wyrosła w kulturze romańskiej, upowszechniona w całej Europie. Stanowi niejako dowód żywotności tradycji, powtarzalności zjawisk i ciągłości kultury ${ }^{26}$. Jest w tym zatem bardzo podobny do „mitu”.

Sonet to także gatunek o bardzo wysokim stopniu sformalizowania, „symetryczny”, o wyraźnie dychotomicznej budowie. Przy interpretacji w perspektywie intertekstualnej istotny okaże się tradycyjny podział na część opisową (pierwsze dwie, czterowersowe strofy) i refleksyjną (kolejne dwie strofy, trzywersowe). Iwaszkiewicz otwiera swój sonet opisem - jego przedmiotem w warstwie dosłownej jest sycylijska fontanna Źródło Aretuzy, będąca świadkiem upływu czasu, a zarazem symbolicznym punktem spotkania obszarów kultury europejskiej. W poetyckim opisie zwraca uwagę nie tylko umiejscowienie przestrzenne, ale także czasowe (przeplatanie się czasu przeszłego, teraźniejszego i przyszłego ${ }^{27}$ ). Dominują barwy ciemne (dwukrotnie powtórzone: „noc”, „,czarny”), metaforyka audialna i akwatyczna. Dwie pierwsze strofy znajdują się niejako w opozycji do kolejnej pary, w której pojawia się opis dźwięku skrzypiec, ruchliwej melodii o wysokim tonie. Iwaszkiewicz wprowadza słownictwo związane z powietrzem („eter”, „niezwiewny”, „podniebny”). Tak wysoce zmetaforyzowany to opis, że sam w sobie nie daje się odnieść do konkretnej kompozycji. Umożliwia to dopiero tytuł, kontekst całego cyklu - poświęconego Szymanowskiemu - oraz kontekst biograficzny ${ }^{28}$. Ta pobieżna analiza pozwala dostrzec antytetyczny w niektórych aspektach kształt utworu literackiego - kształt wynikający z reguł genologicznych.

25 J. Sławiński, Sonet, [w:] Słownik terminów literackich, red. J. Sławiński, Wrocław 1998, s. 517-518.

26 M. Semczuk, Sonet, [w:] Słownik literatury polskiej XX wieku, red. A. Brodzka i in., Wrocław 1992, s. 1021-1023.

27 Trójdzielność czasu, w którym zanurzone są wytwory kultury, przypomina wspomnianą wyżej koncepcję „inspiracji” i „rezonansu”.

28 J. Iwaszkiewicz, Książka o Sycylii, dz. cyt., s. 138-140. 


\section{Określenia wykonawcze a semantyka dzieła}

Dzieło muzyczne, choć wyraża treści niekonkretne i w sposób nieprecyzyjny ${ }^{29}$, nie jest w swojej naturze asemantyczne ${ }^{30}$, a odautorskie komentarze to kolejny element, który dookreśla perspektywy jego znaczeń $^{31}$. Szymanowski opatrzył swój utwór określeniami delicatamente, sussurando, flessibile, czyli „delikatnie”, „szepcząc”, „giętko”32, w ten sposób opisując jego charakter, ale też modulując i precyzując sposób odbioru muzyki, reagowania na konstrukcję $w$ rozumieniu referencjalnym Krzysztofa Meyera ${ }^{33}$. Ich znaczenie w analizie i próbach określania ewentualnej semantyki Źródła Aretuzy są oczywiste, ale okazują się one kluczowe również dla właściwości intertekstualnych dzieła. Określenia wykonawcze tylko w pewnym stopniu stanowią opis wrażeń akustycznych, uderza natomiast ich metaforyczny ${ }^{34}$ i uniwersalny charakter. Śledząc partyturę, natkniemy się na podobne, przenośne sformułowania, na przykład: perdendosi, leggiero, leggierissimo. Wiele określeń wykonawczych ze swej natury jest przenośniami, warto jednak zwrócić uwagę na pewne semantyczne pokrewieństwo powyższych przykładów i fakt, że z powodzeniem można byłoby zastosować je - również jako metafory - do opisu obrazu ewokowanego w Iwaszkiewiczowskim sonecie. Jako elementy języka naturalnego ${ }^{35}$, pozostające jednak składnikiem dzieła muzycznego (określają nie tylko wykonawstwo, ale charakter utworu samego $\mathrm{w}$ sobie $\left.{ }^{36}\right)$, a jednocześnie pewnym metatekstem wobec niego ${ }^{37}$, mogą być na różne sposoby przeszczepiane na grunt literatury. To, co w dziele muzycznym jest metatekstem, dla

29 L. Polony, Muzyka w perspektywie hermeneutycznej, [w:] Intersemiotyczność. Literatura wobec innych sztuk (i odwrotnie), red. S. Balbus, A. Hejmej, J. Niedźwiedź, Kraków 2004, s. 265.

30 A. Barańczak, Jak muzyka... dz. cyt., s. 121-122. O „treści” muzyki pojmowanej jako system językowy przekonuje także Hans Heinrich Eggebrecht. Por. A. Nowak, Hans Heinrich Eggebrecht i muzyka jako mowa dźwięków, [w:] Analiza i interpretacja dzieła muzycznego, dz. cyt., s. 263-272.

31 Por. M. Piotrowski, Allegro con fuoco, „Teksty” 1978, nr 1, passim.

32 T. Chylińska, dz. cyt., s. 341.

33 Za: I.D. Bent, dz. cyt., s. 65.

34 J. Kmita, Z metodologicznych problemów interpretacji humanistycznej, Warszawa 1971, s. 38; cyt. za: M. Piotrowski, dz. cyt., s. 183.

35 M. Piotrowski, dz. cyt., s. 177.

36 S. Dąbrowski, dz. cyt., s. 151.

37 Por. M. Piotrowski, dz. cyt., s. 179-18o. 
pisarza może mieć w tym przypadku charakter dyrektywny. Do poszukiwań literackiej realizacji wskazówek Szymanowskiego skłania fakt kompozytorskich kompetencji Jarosława Iwaszkiewicza ${ }^{38}$.

Charakter obu dziełnajlepiejoddajeokreślenie „szepcząc”" (sussurando). Poeta nasyca swój tekst leksyką związaną z dźwiękiem. W części opisowej są to: „jęlk”, „szelest”, „cichy”, „gruchanie”, „cisza”, w drugiej połowie zaś: „ton wysoki” oraz „dzwoni”, te jednak nie odnoszą się do opisu dźwięków tła, a do opisu dźwięku instrumentu. Charakterystyka przestrzeni dokonuje się z wykorzystaniem arsenału określeń korespondujących z „szeptem”. Dźwięki rozbrzmiewają cicho i „delikatnie” (delicatamente). Kolejne z określeń wykonawczych Szymanowskiego Iwaszkiewicz realizuje więc nie tylko $\mathrm{w}$ słownictwie związanym $\mathrm{z}$ dźwiękiem, ale i $\mathrm{w}$ warstwie eufonicznej. „Giętko” (flessibile) wydaje się najbardziej swobodną metaforą zarówno w stosunku do utworu muzycznego, jak i do sonetu, ale i w tym przypadku odnajdziemy dalekie skojarzenie z treścią mitu oraz poetyckiego opisu - giętką trzciną papirusową, obecną w obrazie poety.

Określenia wykonawcze są zatem kolejnym „literackim” elementem kompozycji istniejącym w dziele poetyckim. Nawet jeśli w myśl negatywnej koncepcji Szulca literatura nie może dostarczać czysto muzycznych wrażeń, to odwołuje się czasem do tych samych kręgów skojarzeniowych co muzyka. Echa tych jakości estetycznych kompozycji wybrzmiewają poprzez medium ${ }^{39}$, jakim jest sonet, a konkretniej - przez metafory i symbole, które ze swej natury także rysują jedynie ogólne perspektywy znaczeniowe.

\section{Kompozycja jako temat}

Źródło Aretuzy Szymanowskiego, oprócz statusu wzorca, który w różnych aspektach determinuje cechy sonetu Iwaszkiewicza, ma także status przedmiotu opisu w wierszu. Ze względu na formalne ograniczenia gatunkowe opis ten jest zwięzły i wybiórczy - zajmuje tylko

38 A. Matracka-Kościelny, Komponowanie dźwiękiem i słowem $w$ twórczości Jarosława Iwaszkiewicza, [w:] Muzyka w literaturze. Antologia..., dz. cyt., s. 195. Autorka przytacza także słowa samego Iwaszkiewicza (tamże, s. 206), który dostrzegał analogie pomiędzy literackim i kompozytorskim procesem twórczym. Ta niecodzienna dwuaspektowość umiejętności jest kolejnym argumentem za czytaniem wierszy poety w perspektywie intertekstualnej.

39 A. Hejmej, Muzyczność..., dz. cyt., s. 50. 
sześć wersów i dotyczy jedynie niektórych aspektów dzieła muzycznego ${ }^{40}$. O fakcie, że tematem wiersza jest kompozycja Szymanowskiego, świadczą zanalizowany wyżej tytuł, kontekst biograficzny oraz wzmianka o Antoniu Stradivarim (mowa zatem o muzyce przeznaczonej na skrzypce). Posługując się klasyfikacją Konrada Górskiego ${ }^{41}$, można zaryzykować stwierdzenie, że opis ten jest syntezą pierwiastka subiektywnego i obiektywnego. Warto postawić tu pytanie o status utworu - czy w świecie poetyckim istnieje Źródło Aretuzy Szymanowskiego czy może dowolne wyobrażenie Iwaszkiewicza o wieloznacznym $z$ natury dziele przyjaciela, zapis wrażeń poety, przy całym jego muzycznym wykształceniu - jednak subiektywnych? Odpowiedzi na to pytanie dostarcza kilka faktów. Pierwszym z nich jest zasygnalizowane $\mathrm{w}$ dalszej części pracy podobieństwo opisu muzykologicznego i poetyckiego, co sugeruje pokrewieństwo tych dróg recepcji kompozycji. Drugim - zgoda wielu badaczy co do istnienia w dziele muzycznym informacji odnośnie do jego semantyki. Można więc stwierdzić, że kompozycja dostarcza niesprecyzowanych sugestii jej rozumienia i że do pewnego stopnia rozumie się je jednakowo ${ }^{42}$. Iwaszkiewicz, interpretując Źródło Aretuzy Szymanowskiego i otaczając je danymi symbolami oraz przedmiotami, subiektywizuje i konkretyzuje jedynie dokładniej obiektywne znaczenia wpisane $\mathrm{w}$ dzieło muzyczne samo w sobie. Co więcej - jego opis odnosi się nie tylko do ubogiej warstwy znaczeniowej utworu, ale może przede wszystkim do jego budowy, której realizację zmysłowo odbieramy.

W poetyckim opisie kompozycja rozpoczyna się „wysokim tonem” skrzypiec - w partyturze zaczyna się ona od $a^{3}$ i na tle fortepianu brzmi bardzo jasno. Szymanowski w pierwszych dwudziestu pięciu taktach (przed poco agitato i accelerando) rezygnuje z dużych skoków interwałowych, które występują sporadycznie i są łagodzone glissandami (takty 16 i 17) oraz artykulacją legato. Dźwięki zmieniają się delikatnie, nie zaskakując nagłymi przyspieszeniami czy zmiennością rytmu, jednak w całej pierwszej sekwencji fraz (takty 9-26) melodia jest ruchliwa,

40 Jak ukazują badacze, zjawisko to jest nieuniknione, dzieło muzyczne jako całość nie jest bowiem opisywalne słownie. Por. B. Pociej, Opis - analiza - interpretacja (na materiale Elementi $i$ Canti instrumentali Henryka M. Góreckiego), „Res Facta” 4 (1970), s. 153-154; cyt. za: S. Dąbrowski, dz. cyt., s. 155.

41 K. Górski, Muzyka w opisie literackim, [w:] Muzyka w literaturze. Antologia..., dz. cyt., s. 271.

42 A. Barańczak, Poetycka „muzykologia”, dz. cyt., s. 42-43. 
nieczęsto prowadzona wartościami dłuższymi niż ćwierćnuta. Wydaje się, że ta łagodność oraz ruchliwość melodii mają pewną analogię w tekście. Iwaszkiewicz konstruuje opis przy pomocy dużego zagęszczenia czasowników: „zjawia się, , ,bierze”, „zatrzymuje się”, „zniża”, „opiera się" i „dzwoni”. Są to słowa kojarzące się z ruchem, dynamiką. W wypowiedzi poety zaznacza się synteza poetyckiego i „kompozytorskiego" myślenia o muzyce. „Wysokość" tonu ma znaczenie zarówno w sensie muzykologicznym, jak i w sensie symbolicznym, bowiem dla pisarza charakterystyczne jest zainteresowanie perspektywą wertykalną ${ }^{43} \mathrm{i}$ właśnie w ten sposób postrzega on muzykę, o czym świadczy wzbogacenie jej opisu leksemami pośrednio nawiązującymi do wysokości. „Czysty” odnosi się zapewne do brzmienia skrzypiec, ale w otoczeniu przestrzeni naznaczonej śmiercią jawi się jako „nieskażony jej wpływem”. Iwaszkiewicz tworzy i wyzyskuje polisemiczność słów, umieszczając je jednocześnie w kontekście muzycznym i pozamuzycznym. Dzięki temu muzyka zdaje się odpowiadać zjawiskom i jakościom natury.

Źródło Aretuzy Szymanowskiego jako kompozycja istnieje zatem w sonecie w sensie dosłownym, w świecie kreowanej w dziele fikcji literackiej. Biorąc pod uwagę funeralny kontekst całego cyklu Sonetów sycylijskich, można wysnuć wnioski o wyjątkowym statusie tego właśnie dzieła kompozytora, stanowiącego dlań, nomen omen, źródło nieśmiertelności. Na pytanie o powód takiego stanu rzeczy odpowiadają częściowo biografie twórców, dla których Sycylia miała duże znaczenie tak w życiu osobistym, jak i artystycznym. Muzyczne Źródło Aretuzy staje się synekdochą całej twórczości Szymanowskiego, spoiwem tradycji i nowoczesności, kultury europejskiej i kultury polskiej. Iwaszkiewicz dostrzega, że dzieło przyjaciela łączy w sobie różne pierwiastki i dlatego wiąże jego kompozycję z sycylijskim źródłem Aretuzy - umownym centrum historyczno-geograficznym Europy, punktem stycznym cywilizacji greckiej i rzymskiej ${ }^{44}$. Poetyzacja kompozycji sugeruje jej zdolność do przetrwania po śmierci twórcy. Źródło Aretuzy Szymanowskiego istnieje w sonecie także jako sięgający antyku symbol - symbol twórczości zapewniającej nieśmiertelność autora, eschatologiczny symbol przestrzeni metafizycznej.

43 I. Maciejewska, „Pociecha mieszka w pięknie”(Jarosław Iwaszkiewicz: Śpiewnik włoski), [w:] O twórczości Jarosława Iwaszkiewicza, red. A. Brodzka, Kraków 1983, s. 89.

44 J. Iwaszkiewicz, Spotkania z Szymanowskim, Kraków 1981, s. 71. 


\section{Ukształtowanie dźwiękowe tekstu}

Obecność kompozycji na poziomie przedmiotu wypowiedzi literackiej często ma poważne konsekwencje w formalnej analizie. Tematyzowanie muzyki ma bowiem

\section{[...] wewnątrztekstowe znaczenie relacyjne, [...] bardzo często sfunkcjonali- zowane jest w taki sposób, by spełniać na poziomie metatekstowym funkcję ważnego komentarza, bez którego niejednokrotnie i zjawiska muzyczności I, i muzyczności III pozostają niezauważone ${ }^{45}$.}

W tym przypadku elementy poetyckiego opisu kompozycji każą zadać pytanie o inne formy prób przeniesienia muzyki do literatury. Muzyczność rozumiana jako ogół brzmieniowych właściwości tekstu skupia się na zjawiskach, do których wyjaśnienia wystarcza często poetyka opisowa ${ }^{46}$, może jednak, na zasadzie analogii, czerpać inspiracje z dźwięków muzyki. Wspomniana wyżej dychotomia niejako wymuszona formą została przez Iwaszkiewicza podparta ukształtowaniem dźwiękowym wiersza. Warto tu nakreślić charakterystyczne zjawiska w zakresie jego warstwy brzmieniowej. W pierwszej połowie sonetu (strofy I i II) dominują rozbudowane zdania pokrywające się z długością trzynastozgłoskowych wersów. Senność opisu krajobrazu wspierają onomatopeje, instrumentacja głoskowa („szelest usłyszysz”, „czarną paszczę"). Odgłosy nocy i wody nie są jedynie przedmiotem opisu, one subtelnie brzmią w tekście. Składniowe i dźwiękowe ukształtowanie tekstu zmienia się $\mathrm{w}$ dwóch kolejnych strofach. Tok poetyckiej wypowiedzi przyspiesza i wyraźnie się komplikuje ${ }^{47}$, zdania są krótsze, urywane. W miejsce rozbudowanych jednostek składniowych pojawia się wyliczenie pojedynczych czasowników związanych z ruchem oraz określenia połączone występującym aż sześciokrotnie spójnikiem „i”. W warstwie eufonicznej zwraca uwagę dwukrotne akcentowanie „o" na początku opisu $^{48}$. Dwa razy zastosowano także myślnik, który jeszcze bardziej rozbija poetycką frazę. Znaczenie kontrastu tych opisów jest jasne w toku

45 A. Hejmej, Muzyczność..., dz. cyt., s. 63. Muzyczność I dotyczy warstwy brzmieniowej tekstu, zaś muzyczność III - konstrukcji. Dokładną charakterystykę przyjętej klasyfikacji muzyczności zob. tamże, s. 53-67.

46 Zob. Cz. Zgorzelski, dz. cyt., passim.

47 J. Kwiatkowski, Poezja Jarosława Iwaszkiewicza na tle dwudziestolecia międzywojennego, Warszawa 1975, s. 538.

48 Tamże. 
analizy wiersza samego w sobie, warto jednak postawić sobie pytanie o związki takiej budowy ze Źródłem Aretuzy Szymanowskiego.

Jak wspomniano, akwatyczna metaforyka pierwszych dwóch strof łączy się z nasyceniem tekstu wrażeniami słuchowymi. Właśnie owo połączenie okazuje się kolejnym śladem kompozycji w sonecie. Sam Szymanowski mówił o "tonacji głównej «płynącej wody»" 49, co sugeruje zamysł budzenia dźwiękiem określonych skojarzeń, impresjiiso. Możliwe, że Iwaszkiewicz, choć mógł nie znać tej wypowiedzi przyjaciela, odczytał jego intencje i we własnej wersji Źródła Aretuzy użył określeń związanych z wodą - co tłumaczy się nie tylko opisem sycylijskiego zabytku. Trudno mieć pewność co do tego, w jakim stopniu działanie poety jest intencjonalne, jednak pewne pokrewieństwo obrazowania (w zakresie dopuszczalnym przez ograniczone możliwości działań intersemiotycznych) w obu tekstach występuje niewątpliwie.

\section{Analogie w konstrukcji - instrumentacja a poetyckie obrazy}

Co oczywiste - konstrukcja muzyczna nie może zostać dosłownie przeniesiona do dzieła literackiego, może jednak zostać w nim zinterpretowana $^{51}$. Nie ulega wątpliwości, że do skrzypiec przynależą strofy III i IV, „ton” zjawia się „nagle”. W partyturze melodia skrzypiec pojawia się $\mathrm{w}$ takcie dziewiątym, czyli po ośmiotaktowej prezentacji partii fortepianu, traktowanego jako "równouprawniony solista" ${ }^{52}$. I tak - jeśli kompozycję możemy traktować jako nierozerwalną całość złożoną z partii fortepianu i skrzypiec, a poetycką deskrypcję melodii tych ostatnich bez trudu odnajdujemy w sonecie, musimy zadać sobie pytanie o pozycję partii fortepianu i jej ewentualne istnienie w tekście. Pewne wskazówki w tym zakresie daje zreferowana wcześniej opozycja tematyczna (opis źródła - opis melodii) wsparta ukształtowaniem eufonicznym, na podstawie których partii tekstu prezentującej melodię skrzypiec możemy przeciwstawić strofy I i II, stanowiące tło. Według opisu Teresy Chylińskiej dźwięki chordofonu w kompozycji Szymanowskiego „łączą się w organiczny splot” z „odmaterializowaną, lotną,

49 T. Chylińska, dz. cyt., s. 341.

50 Tamże, s. 336.

51 A. Barańczak, Poetycka „muzykologia”, dz. cyt., s. 37.

52 T. Chylińska, dz. cyt., s. 340. 
przejrzystą"53 muzyką fortepianu - analogicznie „ton wysoki”, „uparcie niezwiewny", „bierze w posiadanie" malowany ciemnymi barwami pejzaż sycylijskiego źródła Aretuzy.

Uderzająca jest obecność w naukowym muzykologicznym opisie słownictwa odnoszącego się do powietrza, tak ważnego w opisie poetyckim $^{54}$. Fakt ten świadczy o pokrewieństwie recepcji, dowodzi działania konotacji wywoływanych tytułem kompozycji oraz przyporządkowaniem gatunkowym, ale nie tylko, bo sformułowania poety i badaczki wykazują podobieństwo na bardzo wielu obszarach. Można byłoby hipotetycznie pytać, jakie cechy kompozycji samej w sobie wpływają na asocjacje słuchacza ${ }^{55}$, nie ma jednak miejsca w niniejszej pracy na rozstrzygnięcie tej złożonej i trudnej do zbadania kwestii.

Źródło Aretuzy Szymanowskiego jest wzorcem, który udziela sonetowi jakości estetycznych luźno definiowanych określeniami wykonawczymi. W świetle powyższych rozważań o dychotomicznej budowie wiersza warto zaryzykować stwierdzenie, że kompozycja stanowi również reinterpretowany wzorzec formalny, a precyzyjniej - niektóre cechy struktury utworu muzycznego są punktem wyjścia ${ }^{56}$ dla analizy konstrukcji sonetu. Mowa tu właśnie o obsadzie wykonawczej, o współgraniu skrzypiec i fortepianu. Takie rozwiązanie kompozytora sprawia, że jego dzieło, choć rozpatrywane na różnych płaszczyznach, ma w sobie pewną konstrukcyjną dwudzielność, widoczną w partyturze, i wyczuwalną w samym utworze. Treściową i kompozycyjną dwudzielność wykazuje także sonet Iwaszkiewicza i choć ta analogia jest zbyt słabą przesłanką, by mówić o korelacji w budowie tekstów, to w chwili, gdy uświadomimy sobie, że partia skrzypiec ma odpowiednik w literackim opisie, odpowiedniość partii fortepianu (delica-

53 Tamże.

54 Opisu muzyki, mimo jego subiektywności, nie należy ignorować, ponieważ użyte w nim sformułowania często stanowią dowód semantycznego charakteru dzieła muzycznego, nawet jeśli znaczenia kompozycji nie są konkretne. Zwraca na to uwagę Eggebrecht. Por. A. Nowak, dz. cyt., s. 270-271.

55 Kwestia ta nie dotyczy tylko opisu Chylińskiej. W muzykologicznym opisie Źródła Aretuzy również Zieliński metaforyzuje język, pisząc o „obrazie pogody” i „dziewczęcej szczęśliwości”. Zob. tenże, dz. cyt., s. 110. Badacz jasno określa, jakie skojarzenia budzą w nim poszczególne elementy kompozycji, używając słownictwa, które znajduje się $\mathrm{w}$ tych samych polach semantycznych, co określenia Chylińskiej i poezja Iwaszkiewicza.

S. Dąbrowski, dz. cyt., s. 151. 
tamente, sussurando, flessibile) i opisu krajobrazu staje się przekonywającą hipotezą.

\section{Podsumowanie}

Bezpodstawnym byłoby nieprzejednane stanowisko, jakoby muzyka mogła istnieć wyłącznie w materiale dźwiękowym. Owszem, dzieło muzyczne jako całość może być realizowane jedynie poprzez zjawiska akustyczne, nie można jednak ignorować przebogatej historii wzajemnych wpływów literatury i muzyki oraz faktu, że literaci często programowo odwołują się do muzycznych schematów. Powyższe rozważania miały na celu rozstrzygnięcie kwestii bezpośredniego wpływu kompozycji Karola Szymanowskiego na konkretny utwór liryczny Jarosława Iwaszkiewicza ${ }^{57}$. Wskazanie wszystkich płaszczyzn literatury, na których może istnieć dzieło muzyczne, jest niemożliwe ze względu na niekonwencjonalność i zróżnicowanie zjawiska. W świetle powyższej analizy konkretnych przykładów można jednak zdefiniować niektóre ze sposobów operacji intersemiotycznej. Tytuł i określenia wykonawcze utworu, jako „literackie” elementy kompozycji, stwarzają pewne perspektywy interpretacyjne, budzą określone skojarzenia. To płynne znaczenie dzieła muzycznego jest siłą rzeczy konkretyzowane przez poetę, posługującego się systemem nieporównywalnie bogatszym semantycznie. Semantyka literatury i dzieła muzycznego różni się znacznie i działa inaczej, można jednak znaleźć miejsca wspólne dzięki literackim właściwościom tytułu, określeń wykonawczych i gatunku. Wpływ tego ostatniego na przekładalność aspektów kompozycji z powrotem na język literacki wymagałby osobnej rozprawy, jednak warto przynajmniej go zasygnalizować. Źródło Aretuzy Szymanowskiego jako całość istnieje $\mathrm{w}$ tekście także na najbardziej podstawowym poziomie przedmiotu opisu, ma jednak wielorakie znaczenie:

a) dosłowne - opis dotyczy jej samej,

b) symboliczne - uzupełnia poetycką wizję przestrzeni zjednoczonej kultury,

c) metaforyczne - reprezentuje całą twórczość kompozytora.

57 Związki te były oczywiście dostrzegane, jednak zazwyczaj zatrzymywały się na poziomie kontekstu biograficznego lub lapidarnej informacji o muzyce w charakterze tematu. 
Treściowa, genologiczna i dźwiękowa dwudzielność tekstu staje się podstawą do wysnucia hipotezy o próbie odwzorowywania muzycznej dwuwarstwowej budowy w zakresie obsady wykonawczej. Takie zabiegi konstruowania tekstów w oparciu o konstrukcję kompozycji są znane literaturze. W analizowanym przykładzie przesłanki są wystarczająco mocne, by stwierdzić, że reinterpretowana w duchu licentia poetica budowa kompozycji istnieje w tekście literackim. Związki i sposoby istnienia kompozycji poza muzyką to temat bardzo obszerny, wymagający nie tylko znajomości kanonu obu sztuk, ale i ostrożności metodologicznej, jednak twórczość kompozytorów, którym jak Karolowi Szymanowskiemu nieobca jest działalność literacka, oraz pisarzy o wykształceniu muzycznym i doświadczeniu kompozytorskim wymaga takiego działania. Specyfika tego obszaru pogranicza sztuk, różnorodność i wielość możliwości nastrajają badaczy do pytania o ontologię i semantykę muzyki, co umożliwia interpretatorom literatury dostrzegać jej obecność i określać jej funkcję. Wydaje się, że dziś mamy już do tego narzędzia.

\section{Bibliografia}

Barańczak A., Jak muzyka znaczy, „Teksty” 1976, nr 6.

Barańczak A., Poetycka „muzykologia”, [w:] Muzyka w literaturze. Antologia polskich studiów powojennych, red. A. Hejmej, Kraków 2002, s. 37-44.

Bent I.D., Analiza. Polski przekład hasła $z$ "The New Grove Dictionary of Music and Musicians", tłum. J. Rybicki, [w:] Analiza i interpretacja dzieła muzycznego. Wybór metod, red. T. Malecka, Kraków 1990, seria „Introductio Musicae”, t. 4, s. 5-86.

Chylińska T., Karol Szymanowski i jego epoka, t. 1, Kraków 2008.

Chylińska T., Szymanowski i jego muzyka, Warszawa 1971.

Dąbrowski S., „Muzyka w literaturze” (próba przeglądu zagadnień), [w:] Muzyka w literaturze. Antologia polskich studiów powojennych, red. A. Hejmej, Kraków 2002, s. 145-170.

Głowiński M., Gatunki literackie w muzyce, [w:] Klasycy współczesnej polskiej myśli humanistycznej, red. R. Nycz, t. 2, Narracje literackie i nieliterackie, Kraków 1997, s. 183-188. 
Głowiński M., Literackość muzyki - muzyczność literatury, [w:] Muzyka w literaturze. Antologia studiów powojennych, red. A. Hejmej, Kraków 2002, s. 101-121.

Górski K., Muzyka w opisie literackim, [w:] Muzyka w literaturze. Antologia polskich studiów powojennych, red. A. Hejmej, Kraków 2002, s. 259-284.

Graves R., Mity greckie, tłum. H. Krzeczkowski, Warszawa 1968.

Hejmej A., Muzyczność dzieła literackiego, Wrocław 2002.

Iwaszkiewicz J., Książka o Sycylii, Warszawa 2000.

Iwaszkiewicz J., Martwa pasieka, [w:] Opowiadania muzyczne, Warszawa 1971.

Iwaszkiewicz J., Spotkania z Szymanowskim, Kraków 1981.

Kwiatkowski J., Poezja Jarosława Iwaszkiewicza na tle dwudziestolecia międzywojennego, Warszawa 1975.

Maciejewska I., „Pociecha mieszka w pięknie” (Jarosław Iwaszkiewicz: Śpiewnik włoski), [w:] O twórczości Jarosława Iwaszkiewicza, red. Alina Brodzka, Kraków 1983, s. 87-108.

Matracka-Kościelny A., Komponowanie dźwiękiem $i$ słowem w twórczości Jarosława Iwaszkiewicza, [w:] Muzyka w literaturze. Antologia polskich studiów powojennych, red. A. Hejmej, Kraków 2002, s. 195-216.

Nowak A., Hans Heinrich Eggebrecht $i$ muzyka jako mowa dźwięków, [w:] Analiza i interpretacja dzieła muzycznego. Wybór metod, red. T. Malecka, Kraków 1990, seria Introductio Musicae, t. 4, s. 263-272.

Piotrowski M., Allegro con fuoco, „Teksty” 1978, nr 1.

Polony L., Muzyka w perspektywie hermeneutycznej, [w:] Intersemiotyczność. Literatura wobec innych sztuk (i odwrotnie), red. S. Balbus, A. Hejmej, J. Niedźwiedź, Kraków 2004, s. 259-268.

Semczuk M., Sonet, [w:] Słownik literatury polskiej XX wieku, red. A. Brodzka i in., Wrocław 1992.

Sławiński J., Sonet, [w:] Słownik terminów literackich, red. J. Sławiński, Wrocław 1998.

Tomaszewski M., Między inspiracja a rezonansem. Dzieło muzyczne w perspektywie intertekstualnej, [w:] Analiza dzieła muzycznego. Historia, theoria, praxis, t. 1, red. D. Kanafa, Wrocław 2010. 
Zgorzelski Cz., Elementy „muzyczności” w poezji lirycznej, [w:] Muzyka $w$ literaturze. Antologia polskich studiów powojennych, red. A. Hejmej, Kraków 2002, s. 79-100.

Zieliński T., Szymanowski. Liryka i ekstaza, Kraków 1997.

\section{Abstract}

Two Fountains of Arethusa. Semantics, literary qualities, and functioning of aspects of Karol Szymanowski's composition in Jarosław Iwaszkiewicz's sonnet.

The purpose of this article is to define the possible meanings and connotations of musical compositions and their conversion into the lingual substance of poetry. Since the issue is varying internally and always needs particular examples, the undertaken analysis concerns two pieces of art: Fountain of Arethusa by a Polish composer Karol Szymanowski and a sonnet of the same title written by his friend and relative, writer Jarosław Iwaszkiewicz. Firstly, the matter of literary title and its associations is compared in both pieces, which leads to conclusion that while the name of composition generates loose and imprecise connotations, literature requires more specification, nonetheless both the composer and the poet understand mythical subject alike and reception of the work of the latter is based on emotional and semantic qualities similar to those included in the composition. Then, the subject of musical genre is depicted, with emphasis placed on literary connotations and their implications in the process of transcription of music into words. As the poet uses sonnet, which apparently has got poor connections to music, the motives of such choice are enumerated, including significance in European culture and interior dichotomy, both of which one can find in Szymanowski's work. Further, the article describes relations between music character indications in musical score and particular lexemes in the poem. Musical work can exist in literature in many ways, first of which is being a theme of objective or subjective description. Such illustration of music in the poem is analysed. Then the euphonious and rhythmic features of the text are described in order to prove that music exists in the sonnet in its sound as well as being a scheme which is reinterpreted and imitated by the 
writer. The analysis shows that although one cannot translate musical matter into words, it is impossible to ignore many intersemiotic correlations between music and literature. Every example of such coexistence - either on the ground of semantics or form - must be studied individually.

\section{Keywords}

Karol Szymanowski, Jarosław Iwaszkiewicz, semiotics, intertextuality, comparison of arts 